\title{
SPATIAL VARIABILITY OF SELECTED SOIL PROPERTIES OF THE LOWER NIGER RIVER FLOODPLAINS IN BAYELSA STATE, NIGERIA
}

\author{
Achimota A. Dickson' ${ }^{1}$, Joseph O. Tate ${ }^{1 *}$, Payou T. Ogboin ${ }^{3}$, Cameroon O. Payebo $^{2}$ \\ and Williams P. Agbai ${ }^{1}$
}
${ }^{1}$ Department of Soil Science, Faculty of Agriculture, Niger Delta University, Wilberforce Island, PMB 071, Amassoma, Bayelsa State, Nigeria.
${ }^{2}$ Department of Agronomy, Faculty of Natural and Agricultural Sciences, North-West University, Mafikeng, South Africa.
${ }^{3}$ Department of Crop Science, Faculty of Agriculture, Niger Delta University, Wilberforce Island, PMB 071, Amassoma, Bayelsa State, Nigeria.
*Corresponding Author E-mail: j.o.tate@ndu.edu.ng

Cite this article:

Achimota A.D., Joseph O.T., Payou T.O., Cameroon O.P., Williams P.A. (2021), Spatial Variability of Selected Soil Properties of the Lower Niger River Floodplains in Bayelsa State, Nigeria. African Journal of Agriculture and Food Science 4(3), 14-27. DOI: 10.52589/AJAFS6RMAXNLV.

\section{Manuscript History}

Received: 10 June 2021

Accepted: 5 July 2021

Published: 20 July 2021

Copyright $\odot 2020$ The Author(s). This is an Open Access article distributed under the terms of Creative Commons AttributionNonCommercial-NoDerivatives 4.0 International (CC BY-NC-ND 4.0 ), which permits anyone to share, use, reproduce and redistribute in any medium, provided the original author and source are credited.
ABSTRACT: Owing to the influence of topography on soil properties, studies on the variability of soil properties become imperative. This study assessed spatial variability of some selected soil properties in three physiographic units: upper slope, lower slope and recent alluvial soils on channels of present active river in two locations in Bayelsa State. In each unit, one representative soil profile was dug, soil samples collected from generic horizons and analyzed. The results showed varying degree of spatial variability in physical and chemical characteristics, flooding, the source of parent materials and degree of hydromorphism; being the major determining factors. Among the soil separates, clay was highly variable in two physiographic units while sand and silt showed moderate variability. Organic $C$ was moderately to highly variable $(C V=20.13-112.77 \%)$, while total $N(36.53-90.01 \%)$ and available $P(41.49-58.71 \%)$ were highly variable in all the mapping units. Calcium was moderately variable $(C V=26.85 \%)$ in the upper slope, and highly variable in the middle slope $(C V=43.17 \%)$ and moderately variable $(C V=28.93 \%)$ in recent alluvial soils in the channel of the present active river of Elemebiri and in Trofani soils; low (CV=10.01\%) in the upper slope, highly variable $(C V=41.33 \%)$ in the middle slope and moderately variable $(C V=22.08 \%)$ recent alluvial soils in the channel of the present active river while $\mathrm{Mg}(\mathrm{CV}=66.79$ $80.29 \%)$ and $K(C V=39.27-101.53 \%)$ were highly variable in the different physiographic units of the two locations. Flooding, wetness and soil fertility are major constraints to agricultural intensification that requires attention.

KEYWORDS: Variability, Lower Niger River, Floodplain, Physiographic Unit 


\section{INTRODUCTION}

Bearing in mind the heterogeneity and isotopic nature of the soil, proper understanding of the make-up of various soil properties for food production in any food growing area, are important considerations in optimal and sustainable agricultural production. The implications of this in the input-output management as well as cost-benefit analysis of soils before ascertaining its' most appropriate and sustainable usage (Senjobi et al, 2016) cannot be over-emphasized. Little wonder, difficulty in mapping of most tropical soils and challenges in accurately predicting the management and production potentials of tropical soils have long been traced to high degree of variability (Ogunkunle, 2003). It is in realization of this that (Fasina, 2008) posited that the most effective land conservation method is the appropriate allocation of land use to areas where they are most suitable.

Lawal et al, (2019) reported that soil variability in vertical and horizontal directions is dictated by intrinsic and extrinsic factors. Earlier, (Egbuchua, 2014) opined that soil variability could be either spatial or temporal. From (Akinbola et al, 2010), spatial variability in soil properties occurs with distance while temporal variability is a seasonal variation in certain soil properties that display continuous variation depending on the activities in them. (Effiom et al, 2010), opined that variability in soil properties could result in some parts of the field not receiving sufficient inputs such as fertilizer, to enable the crops or plants meet their potential while the other parts receiving excess of it under uniform application. They further reported high degree of variability in plant stands and low average productivity for most tropical Ultisols as one moves from fertile valley bottom to generally infertile upland soils.

In the recent pasts, soil properties variations research has been on the front burner for tropical areas (Egbuchua, 2014) but not in the lower Niger floodplain soils. In spite of the great agricultural potentials of the Lower Niger floodplain soils (Dickson, 2018), not much information on the variability of the soil properties is available to be used as guide for effective soil management. Food crops in the flood plain soils are cultivated on the levee crest, levee slope, backslope and on recent alluvial soils on channels of present active rivers but information on variability in the soil properties are lacking. In this regard, this study was designed to assess the spatial variability of selected soil properties in the levee crest, levee slope, and recent alluvial soils on channels of present active rivers in the lower Niger floodplains of Bayelsa State to aid in location-specific precision agricultural management planning.

\section{MATERIALS AND METHODS}

\section{Description of the Study Areas}

This study was carried out in Bayelsa State in the Niger Delta region, Southern Nigeria. The study locations lie between Latitude $05^{\circ} 22^{\prime} 03.9^{\prime \prime} \mathrm{N}$ and $04^{\circ} 59^{\prime} 08.9^{\prime \prime} \mathrm{N}$ and Longitude $006^{\circ} 30^{\prime}$ $21.1^{\prime \prime} \mathrm{E}$ and $006^{\circ} 06^{\prime} 54.1^{\prime \prime} \mathrm{E}$. The Niger River traverses Nigeria in a North-western to Southern direction with the attendant sediment load ensuring that the delta platform ends up as flat terrain, making it a unique geologic environment. The Niger River flows southward and breaks up into two - the Forcados and Nun Rivers in Bayelsa State. Forcados River demarcating the western border of the state and the Nun River, running north and south down the middle of Bayelsa State, which remains the most direct tributary of the Niger. Elemebiri community on the Lower Niger River and Trofani on the Forcados River (Figure 1) were chosen for the study 
grids as both communities were randomly selected out of the four communities lying within a $200 \mathrm{~km}^{2}$ radius around the first and major tributary of the Niger River. The annual rainfall of the study area is $2000-4500 \mathrm{~mm}$, spread over 8 to 10 months of the year and bimodal, peaking at June and September. The relative humidity averages $80 \%$ all over the state and temperature is fairly constant with a maximum of $30^{\circ} \mathrm{C}$. The natural vegetation zone is tropical rainforest.

\section{Soil sampling and analyses}

Detailed soil survey was conducted on agricultural lands from Elemebiri and Trofani using rigid sampling method. The designation of the soil mapping units (SMUs) of $0-200 \mathrm{~cm}$ depth were ELM1 (Ap-Ap2-B1-B2-C1-C2-C3-C4 horizons), ELM2 (Ap-Ap2-B1-B2-B3-B4-C1-C2 horizons) and ELM3 (A-Ap1-Ap2-C1-C2-C3-C4-C5 horizons) for Elemebiri and TFN1 (AAp-B1-B2-B3-C horizons), TFN2 (Ap-Ap2-B1-B2-C1-C2 horizons) and TFN3 (A-Ap1-Ap2$\mathrm{C} 1-\mathrm{C} 2-\mathrm{C} 3-\mathrm{C} 4$ horizons) for Trofani soils. Details of the soil mapping units and the land area are presented in Table 1. Soil sampling procedures followed the methods prescribed by the USDA Soil Taxonomy (Staff, 2006) and the World Resource Base (Jahn et al, 2006). Three representative soil pedons were dug per location, one each on the levee crest, levee slope and recent alluvial soils in the channel of the present active river, giving priority to where farming is concentrated. The soils were morphologically described in-situ and samples collected from the different horizons for physico-chemical properties determination following standard procedures. Soil samples collected were air-dried, crushed and sieved to pass through a $2 \mathrm{~mm}$ mesh. Analyses were carried out in the Green River Project Laboratory of the Nigerian Agip Oil Company and Zadell Laboratory, Port Harcourt, Nigeria. Standard laboratory methods were used to determine the physical and chemical properties of the soils. Soil particle size analysis was determined using (Day, 1965) method, popularly known as hydrometer method. Soil $\mathrm{pH}$ both in water and $\mathrm{CaCl}_{2}$ (1:2 ratio) was determined using glass electrode $\mathrm{pH}$ meter and electrical conductivity (EC) determined using conductivity meter (Estefan et al, 2013). Organic carbon was determined using the modified dichromate oxidation method of Walkley-Black as described by (Estefan et al, 2013) and the values obtained multiplied by 1.724 (van Bemmelen factor) to obtain organic matter. Total $\mathrm{N}$ was determined using macro-kjeldahl digestiondistillation method as described by (Houba et al, 1995) and available P by Bray P-1 method (Bray \& Kurtz, 1945). Exchangeable acidity was extracted with $1 \mathrm{M} \mathrm{KCl}$ and determined by titration with $\mathrm{NaOH}$ solution using phenolphthalein indicator (Anderson \& Ingram, 1993) and exchangeable Al with 0.01M HCl (Sumner \& Stewart, 1992). Exchangeable cations were extracted with neutral normal ammonium acetate solution as described by (Estefan et al, 2013) and potassium and sodium in the extract measured by flame photometry and calcium and magnesium by atomic absorption spectrophotometry. Cation exchange capacity (CEC) was by the summation method (Kamprath, 1970). The soils were classified using the USDA Soil Taxonomy (Staff, 2006) and the World Resource Base (Jahn et al, 2006).

\section{Data Analysis}

Data were subjected to descriptive statistics. Significantly different means were separated by using Least Significant Difference (LSD) and Standard Deviation (SD). Coefficient of variation $(\mathrm{CV})$ was used for variability analysis where $\mathrm{CV}<15$ is classified as less variable, $\mathrm{CV}$ between $15-35 \%$, classified as moderately variable and $\mathrm{CV}>35 \%$, classified as highly variable. (Wilding \& Drees, 1983). 


\section{RESULTS AND DISCUSSIONS}

\section{Physical properties}

Surface and subsurface texture of the SMUs varied, dominated by silt loam and silty clay loam except ELM3 and TFN3 dominated by sandy loam and loamy sand (Table 2). The dominance of sand in ELM3 and TFN3 indicated the parent materials were deposited under swift moving current. Moreover, these SMUs have the likelihood of high infiltration rate and low water holding capacity with possibility of moisture stress during dry months (Senjobi, 2007; Senjobi et al, 2016). The clay distribution within ELM1, ELM2, TFN1 and TFN2 SMUs was irregular. (Lawal et al, 2013) reported irregular distribution of clay within the subsoil of three pedons, characteristic of cambic horizon. Though the distribution of silt/clay ratio was also irregular with depth, silt/clay ratios generally increased with increase in silt content and vice versa. Higher silt/clay ratio in the surface layers indicated recent annual enrichment of the surface layers through deposition by the annual floods (Table 2).

Texture, organic carbon distribution and clay mineralogy are features commonly used as indicators of the homogeneity or otherwise of the parent materials (Dickson et al, 2021). Textural diversity between the different SMUs was ascribed to different sources of water-borne sediments and flow rate of the flood water at the time of deposition of the parent materials. Whereas the parent materials of ELM3 and TFN3 were probably deposited during the period of high flood under high current, as they are recent alluvial soils from the channels of present active Niger and Forcados Rivers, other profiles were dominated by silt loam, silty clay loam and loam, deposited under slower flow rates of the current. The ELM3 and TFN3 profiles were dominantly constituted by sand-sized particles (sandy loam, loamy sand and sand). The finer soil particles were possibly, in suspension, transported for longer period of time over greater distances and deposited at low flood period when there was less turbulence than the case of ELM3 and TFN3. (Lawal et al, 2013) reported higher amount of silt in JG3 profile of Southern Guinea Savannah of Nigeria and linked it to the seasonal depositional effect of the seasonal stream and the Suleja water reservoir inundating the JG3 area.

\section{Chemical Properties}

The SMUs were moderately acid to neutral, $\mathrm{pH}$ ranging from 5.31 to 7.00 (water) for Elemebiri soils and $5.30-6.80$ (water) for Trofani soils (Figure 2). Wong et al. (2001) reported pH of 6.0 to 7.0 as the optimum $\mathrm{pH}$ for most agricultural crops while (Jahn et al, 2006) and (Brady \& Weil, 2008) gave 5.5 to 7.0 as the preferred range for most crops. Among the SMUs, the surface layers of ELM1 and ELM2 fall below the FAO preferred $\mathrm{pH}$ range. This is an indication that the SMUs need some form of soil amendments. (Khan et al, 2012) attributed increase in soil $\mathrm{pH}$ with depth to ferrolysis which is acidification of topsoil caused by continual displacement of bases by ferrous ion during the reduction phase associated with annual flooding. The exchange acidity of $45 \%$ of the soils was $2.0 \mathrm{cmol} \mathrm{kg}^{-1}$ and above suggesting that $45 \%$ of the soils were slightly to strongly acidic (Ernest \& Onweremadu, 2016).

Organic matter content in the soils generally was low to moderate, ranging from $0.19-3.88 \%$ and $0.37-2.76 \%$ for the Elemebiri and Trofani soils. Total $\mathrm{N}$ was also low to moderate ranging from 0.01 to $0.25 \%$ in Elemebiri soils and 0.01 to $0.13 \%$ in the Trofani soils (Figure 3). Hartz (2007) reported that soils with less than $0.07 \%$ total $\mathrm{N}$ have limited $\mathrm{N}$ mineralization potential, whereas those having values greater than $0.15 \%$ would be expected to mineralize sufficient 
amount of $\mathrm{N}$ during the succeeding crop cycle. Based on this, the surface layers of ELM1, ELM2, TFN1, and TFN3 are likely to have reasonable mineralization potential while the mineralization potential of ELM3 and TFN2 was low.

Organic carbon distribution pattern in the soils indicated stratification. Irregular decrease in organic matter content with depth was consistent with the properties of fluvents (Staff, 2006). The organic C distribution pattern in ELM1, ELM2, ELM3, TFN1, TFN2 and TFN3 (Figure 3) did not suggest uniform parent materials with the observed abrupt increase in organic $\mathrm{C}$ in some horizons down the profile of certain SMUs. Organic C abruptly increased from $0.7 \%$ in the $90-118 \mathrm{~cm}$ layer to $1.07 \%$ in the $150-200 \mathrm{~cm}$ layer of ELM1, $0.11 \%$ in the $42-57 \mathrm{~cm}$ layer to $0.16 \%$ in the $88-106 \mathrm{~cm}$ layer of ELM2, $0.21 \%$ in the $55-140 \mathrm{~cm}$ layer to $1.04 \%$ in the $150-200 \mathrm{~cm}$ layer of TFN2 and $0.30 \%$ in the $38-52 \mathrm{~cm}$ layer to $0.68 \%$ in the $52-69 \mathrm{~cm}$ layer of TFN3 which indicated heterogeneity. Available P ranged from $3-18 \mathrm{mg} \mathrm{kg}^{-1}$ in Elemebiri soils and $3-17 \mathrm{mg} \mathrm{kg}^{-1}$ in the Trofani soils (Table 2) while exchangeable $\mathrm{K}$ varied from $0.18-1.81 \mathrm{cmol} \mathrm{kg}^{-1}$ in Elemebiri and $0.14-1.88 \mathrm{cmol} \mathrm{kg}^{-1}$ in the Trofani soils (Figure 4). Higher $\mathrm{P}$ values were recorded generally in the surface layers revealing the close relationship between organic matter and soil $\mathrm{P}$.

Furthermore, exchange acidity varied from $0.5-2.8 \mathrm{cmol} \mathrm{kg}^{-1}$ in the Elemebiri soils, and 0.8 $-5.4 \mathrm{cmol} \mathrm{kg}^{-1}$ in the Trofani soils while exchangeable Al ranged from $0.3-1.9 \mathrm{cmol} \mathrm{kg}^{-1}$ in the Elemebiri soils and $0.5-2.4 \mathrm{cmol} \mathrm{kg}^{-1}$ in the Trofani soils. Also, the ECEC values were low, ranging from $1.49-6.11 \mathrm{cmol} \mathrm{kg}^{-1}$ in Elemebiri soils and $2.79-6.37 \mathrm{cmol} \mathrm{kg}^{-1}$ in Trofani.

\section{Spatial variability}

From the data in Tables $2-4$ and Figures $2-5$, the complexity of soil property variability in the lower Niger flood plain is very obvious. Consistently, the $\mathrm{pH}$ was the least variable among the topographic units which agreed with the findings of (Mulla \& McBratney, 2001) and (Effiom et al,2010) in the humid region of Nigeria. The variability of the sand, silt and clay in the three different landscapes of the two locations showed similar trend. Sand was moderately variable in the upper and middle slopes and not variable in the recent alluvial soils in the channel of the present active river, silt was not variable in the upper and middle slopes and moderately variable in the recent alluvial soils in the channel of the present active river, while clay was highly variable in the upper and recent alluvial soils in the channel of the present active river and not variable in the middle slope. Clay was the most variable in all the soil mapping units and among the three soil separates (sand, silt and clay). Given, the fact that the parent materials were deposited by the annual floods form the Niger River, sand is expected to be deposited under fast moving current followed by silt when the current slows down to an extent and lastly, clay, under standing water due to their size differences. One expected clay to be dominant in the in the upper and middle slopes. The very high variability of clay in these soils did not reflect that. It is possible the recorded clay distribution is due to variation in parent material or clay distribution has changed due to weathering of the parent materials.

Organic C (CV=20.13 - 112.77\%), was moderately to highly variable while total N (36.53 $90.01 \%)$ and available P $(41.49-58.71 \%)$ were moderately to highly variable in all the soil mapping units, reflecting the positive relationship between organic matter and total $\mathrm{N}$ as well as available $\mathrm{P}$ (Tables 3 and 4). This explains the fact that total $\mathrm{N}$ in these soils is a function of organic matter as $\mathrm{N}$ is stored in organic matter. It is also possible that organic matter 
predominantly contributed to available $\mathrm{P}$ in the soils. Similarly, calcium was found to be moderately variable in the upper slope $(26.85 \%)$ and recent alluvial soils $(28.93 \%)$ in the channel of the present active river of Elemebiri whilst highly variable in the middle slope $(43.71 \%)$ of the same soil. In Trofani soils, low variability in the upper slope $(10.01 \%)$, high variability $(41.33 \%)$ in the middle slope and moderate variability $(22.08 \%)$ in recent alluvial soils in the channel in the active river was recorded. On the other hand, $\mathrm{Mg}$ and $\mathrm{K}$ were highly variable at $(66.79-80.29 \%)$ and $(39.27-101.53 \%)$ respectively in the different landscapes of the two locations. Exchangeable Al was moderately variable in the upper and middle slopes and highly variable in Elemebiri soil while exchange acidity was moderately variable $(21.46 \%)$ in the upper slope and highly variable in the middle slope $(39.96 \%)$ and recent alluvial soils in the channel of the present active river (416.87\%). In the Trofani soil, exchangeable $\mathrm{Al}(39.62$ $-55.02 \%)$ and acidity $(50.06-53.05 \%)$ were highly variable in all the three. The TEB and CEC variability in Elemebiri soil was moderate in the upper and middle slopes and highly variable in the recent alluvial soils in the channel of the present active river. In Trofani soil, TEB was moderate in the upper and middle slopes and highly variable in recent alluvial soils in the channel of the present active river while CEC was moderate in all the physiographic units (Tables 3 and 4), reflecting differences in the source of parent materials and possibly, the degree of hydromorphism.

\section{CONCLUSION}

The floodplain soils of the Lower Niger River and one of its main tributaries (Forcados) showed varying degree of spatial variability in physical and chemical characteristics, the degree and the pattern of flooding, the source of parent materials and degree of hydromorphism, being the major factors moulding variability. Parent materials were of mixed origin and seasonal inundation by the flood water and dryness in the dry season set the stage for alternate oxidation and reduction, providing the most striking features of the pedochemical environment. Flooding, wetness and soil fertility are major constraints to agricultural intensification and which needs to be addressed.

\section{REFERENCES}

Akinbola, G., Ojo, U., \& Adigun, M. (2010). Variability of properties of some pedons on basement complex of South Westen Nigeria. Proceedings of the 34th Annual Conference of the Soil Science Society of Nigeria 22nd - 26th March, 2010. Ibadan: Soil Science Society of Nigeria.

Anderson, J., \& Ingram, J. (1993). Tropical Soil biology and fertility: A handbook of methods. CAB International.

Barnard, R., de Luca, R., \& Li, J. (2016). First-year undergraduate students' perceptions of lecturer and peer feedback: A New Zealand action research project. Studies In Higher Education, 40(5), 933-944. https://doi.org/10.1080/03075079.2016

Brady, N., \& Weil, R. (2008). The Nature and Properties of Soils (14 ed.). New Jersey, USA: Pearson Princeton Hills.

Bray, R., \& Kurtz, L. (1945). Determination of total, organic and available forms of phosphorus in soils. 59, 39-45. 
Chude, V. (2012). Literature Review on the Soil Fertility Investigation in Southern Nigeria. In V. Chude. Abuja, Nigeria: Federal Ministry of Agriculture and Rural Development.

Day, P. (1965). Particle fractionation and particle size analysis:. In C. Black, Methods of Soil Analysis. Madison: American Society of Agronomy.

Dickson, A., Kutu, F., \& Aruleba, J. (2021). Evaluation of Lower Niger River Floodplain Soils of Bayelsa State, Southern Nigeria for their Agricultural Capabilities. Nigerian Journal of Soil Science, 31(1), 100-117. doi:doi.org/10.36265.njss.2021.310113

Dickson. (2018). Characterisation, classification and suitability evaluation of agricultural soils of selected communities located along various river systems in Bayelsa State, Southern Nigeria. Ph D Thesis, North-West University, Department of Agronomy, Mafikeng, South Africa.

Easton, B. (2012). Does poverty affect health? In K. Dew \& A. Matheson (Eds.), Understanding health inequalities in Aotearoa New Zealand (pp. 97-106). Dunedin, New Zealand: Otago University Press.

Effiom, O., Ayuk, E., \& Thomas, E. (2010). Variability in soil properties along an Udalf toposequence in the humid zone. Kasetsart Journal of Natural Science, 44, 564-573.

Egbuchua, C. (2014). Variability of Soil Properties as influenced by different Land Use Types in an Ultisols of the Tropical Region, Delta State,Nigeria. Agricultura Tropica et Subtropica, 47(2), 43-48. doi:10.2478/ats-2014.0006

Ernest, C. I., \& Onweremadu, E. U. (2016). Classification of soils along Ogochie River Floodplain in Niger-Okpala, Imo State,Southern Nigeria. Journal of Global Research, 2, 78-83.

Estefan, G., Sommer, R., \& Ryan, J. (2013). Methods of Soil, Plant and Water Analysis: A manual for the West Asia and North Africa. International Center for Agricultural Research in the Dry Areas (ICARDA).

Fasina, A. (2008). Irrigation Suitability Evaluation of Asa River Basin Soils, Southeastern Nigeria. International Journal of Soil Science, 3, 35-41.

Hartz, T. K. (2007). Soil Testing for Nutrient Availability: Procedures and Interpretation for California Vegetable Crop Production. University of California, Department of Plant Sciences, Vegetables Research and Information Center. Davis: University of California.

Hossain, M. M., Kpan, Z. H., Hussain, M. S., \& Mazumder, A. R. (2011). Characterisation and classification of some intensively cultivated soils from the Ganges river floodplain of Bangladesh. Dhaka University Journal of Biological Sciences, 20, 71-80.

Houba, V. G., Van Der Lee, J. J., \& Novozamsky, I. (1995). Soil and Plant analysis, part 5B soil analysis procedures, other procedures. Wageningen, The Netherlands: Wagnengin University.

Jahn, R., Blume, H. P., Asio, V. B., Spaargaren, O., \& Schad, P. (2006). Guidelines for soil description (4th ed.). Rome, Italy: Food and Agricultural Organisation, FAO. Retrieved from https://edepot.wur.n1/27622

Kamprath, E. (1970). Soil Acidity and Liming in P.A. Sanchez (ed.) A Review of Soil Research in Tropical Latin America. North Carolina, USA: North Carolina Experimental Station.

Khan, Z. H., Hussain, M. S., \& Ottner, F. (2012). Morphogenesis of Three Surface Water Gley Soils from the Megna Floodplain of Bangledesh. Dhaka University Journal of Biological Sciences, 21(1), 17-27. doi:doi.org/10.3329/dujbs.v21i1.9741 
Lawal, B. A., Ojanuga, A. G., Tsado, P. A., \& Mohammed, A. (2013). Characterization, classification and agricultural potentials of soils of toposequence in southern Guinea Savanna of Nigeria. World Academy of Science, Engineering and Technology International Journal of Agricultural and Biosystems Engineering, 7(5), 148-152. doi:doi.org/10.5281/zenodo.10.5281/zenodo.1088062

Lawal, B. A., Tsado, P. A., Afolabi, S. G., Oguntoye, G. p., \& Ogbodo, C. N. (2019). Spatial varaiability of selected soil properties in a cultivated gravelly landscape in Minna, Niger State, Nigeria. Proceedings of the 43rd Conference of Soil Science Society of Nigeria (pp. 163-169). Markurdi: Soil Science Society of Nigeria.

Li, S., \& Seale, C. (2007). Learning to do qualitative data analysis: An observational study of doctoral work. Qualitative Health Research, 17(10), 1442-1452. https://doi.org/10.1177/1049732307306924

Mulla , D. W., \& McBratney, A. B. (2001). Soil spatial variability. In A. W. Warrick, \& I. A. Physics (Ed.), Soil physics companion. (pp. 343-373). Boca Raton: CRC Press. doi:https://doi.org/10.1201/9781420041651

Ogunkunle, A. (2003). Spatial variability of some chemical properties in two Ultisols mapping units in Southern Nigeria. Soil Survey and Land Evaluation, 6(1), 26-32.

Retrieved from http://pascalfrancis.inist.fr/vibad/index.php?action=getRecordDetail\&idt=8788356

Rush, E. C., Obolonkin, V., Battin, M., Wouldes, T., \& Rowan, J. (2015). Body composition in offspring of New Zealand women: Ethnic and gender differences at age 1-3 years in 2005-2009. Annals Of Human Biology, 42(5), 492-497.

Rush, E., McLennan, S., Obolonkin, V., Cooper, R., \& Hamlin, M. (2015). Beyond the randomised controlled trial and BMI--evaluation of effectiveness of through-school nutrition and physical activity programmes. Public Health Nutrition, 18(9), 1578-1581. https://doi.org/10.1017/S1368980014003322

Senjobi, B. (2007). Comparative Assessment of the Effect of Land Use and Land Use Type on Soil Degradation and Productivity in Ogun State. Thesis, University of Ibadan, Agronomy Department, Ibadan.

Senjobi, B. A., Alabi, K. O., Ajiboye, G. A., \& Adeofun, C. O. (2019). Characterization and classification of soils of a toposequence at Osun sacred grove, Nigeria. Nigerian Journal of Soil Science, 29(1), 77- 86. doi:doi.org/10.36265/njss.2019.290111

Senjobi, B. A., Idehen, R. T., Oduntan, O. O., \& Adesodun, J. K. (2016). Characterization and morphogenetic variability of soils under organic-based oil palm plantations in Southwestern Nigeria. Journal of Organic Agriculture and Environment, 4(1), 17-27. Retrieved from http://www.oaptin.org/index.php/JOAEN/article/view/2

Staff, S. S. (2006). Soil Survey Manual (Complete Print Friendly Version). USDA National Resource Conservation Service.

Sumner, M. E., \& Stewart, B. A. (1992). Soil Crusting: Chemical and Physical Processes (1st ed.). Boca Raton: Lewis Publishers.

Wilding, L. P., \& Drees, L. R. (1983). Spatial variability and pedology/edited by L.P. Wilding, N.E. Smeck, and G.F. Hall. Pedogenesis and soil taxonomy, 83.

Wong, J. C., Lai, K. M., Su, D. S., \& Fang, M. (2001). Avilability of heavy metals for Brassica Chinensis grown in an acidic loam soil amended with domestic and sewage sludge. Water, Air and Soil Pollution, 128, 339-353. doi:doi.org/10.1023/A:1010353107240 
African Journal of Agriculture and Food Science

ISSN: 2689-5331

Volume 4, Issue 3, 2021 (pp. 14-27)

www.abjournals.org

APPENDIX

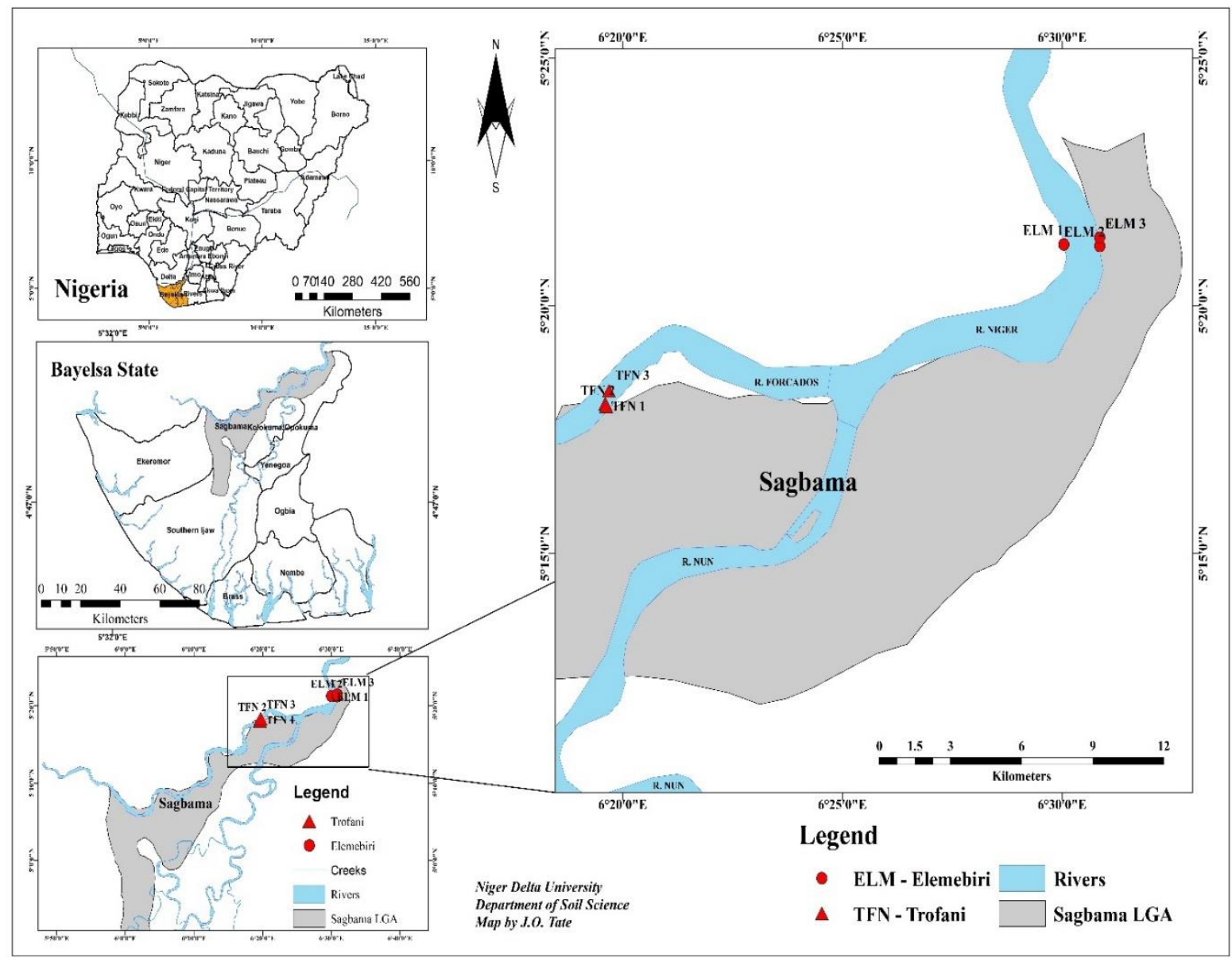

Figure 1: Map Showing the Elemebiri and Trofani Study Areas with profile pit points. 

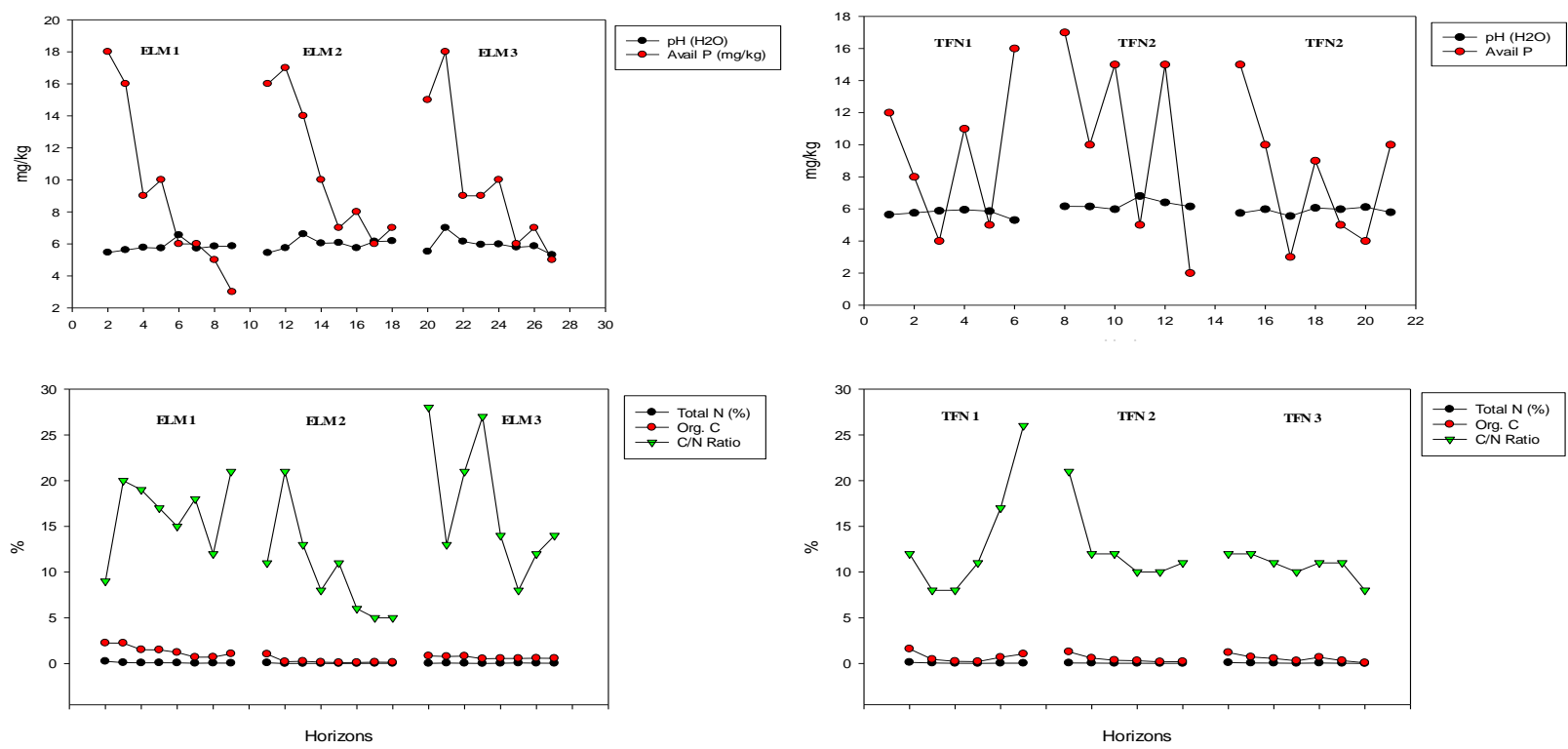

Figure 2. Graph showing distribution of Percent total organic carbon, total nitrogen, $\mathrm{C} / \mathrm{N}$ ratio, $\mathrm{pH}$ and available phosphorus concentration in Elemebiri and Trofani soils.
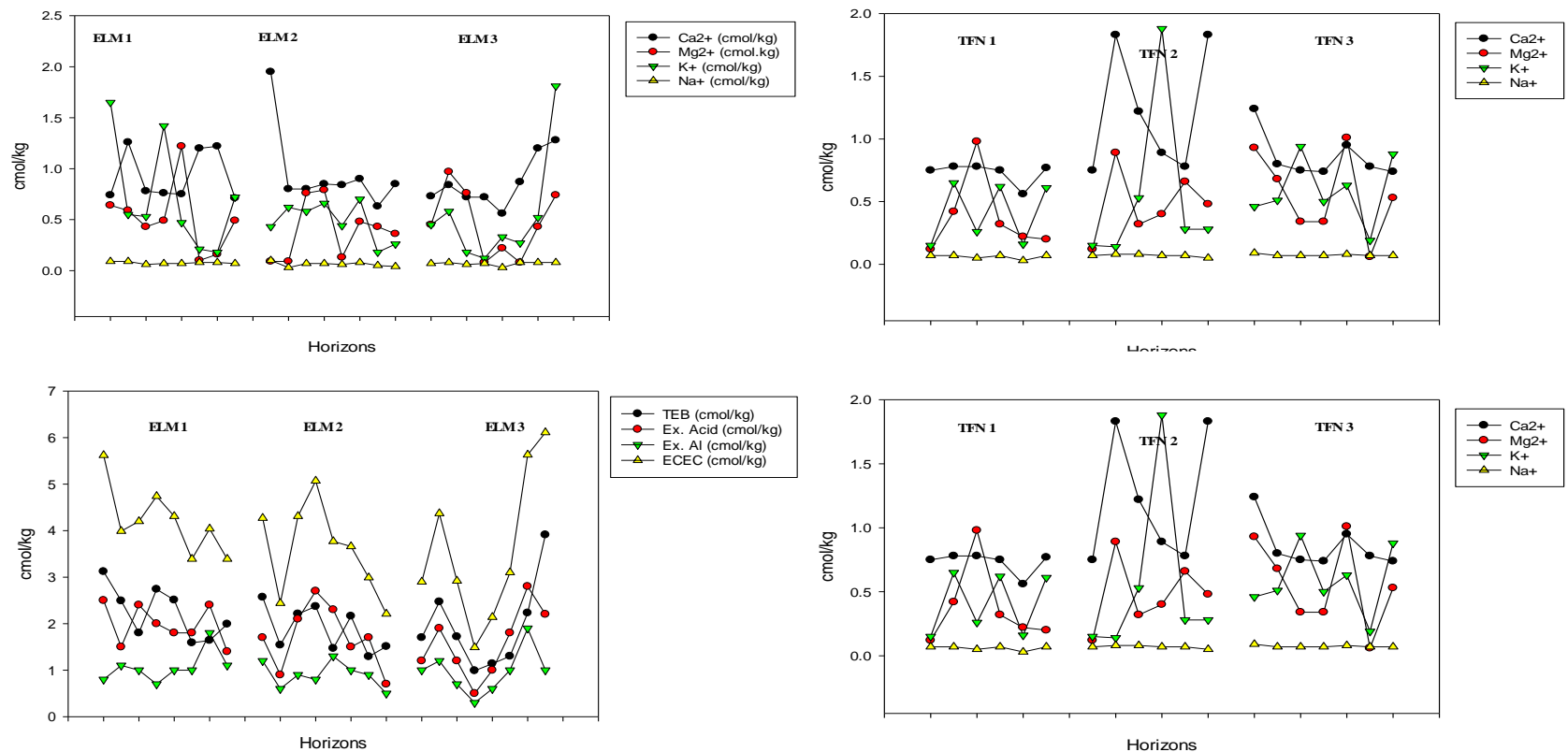

Figure 3. Graph showing distribution of Exch. basic cations, Total Exch. Bases, CEC, Exch. Acidity, Exch. Al and ECEC in Elemebiri and Trofani soils. 
Table 1: Soil Mapping Unit, Profile Pit Location and Land Area

\begin{tabular}{|c|c|c|c|c|c|}
\hline Location & $\begin{array}{c}\text { Soil } \\
\text { Mapping } \\
\text { Unit }\end{array}$ & Geo-reference of Profile Pit & $\begin{array}{l}\text { No. of } \\
\text { Profile } \\
\text { Pit }\end{array}$ & $\begin{array}{c}\text { Land } \\
\text { Area } \\
\text { (ha) }\end{array}$ & $\begin{array}{c}\text { Land } \\
\text { Area } \\
(\%)\end{array}$ \\
\hline \multirow[t]{3}{*}{ Elemebiri } & ELM1 & $\mathrm{N} 05^{\circ} 21^{\prime} 11.5^{\prime \prime}$ E $006^{\circ} 30^{\prime} 02.2^{\prime \prime}$ & 1 & 29.08 & 2.4 \\
\hline & ELM2 & $\mathrm{N} 05^{\circ} 21^{\prime} 12.4^{\prime \prime}$ E $006^{\circ} 30^{\prime} 51.3^{\prime \prime}$ & 1 & 21.25 & 1.7 \\
\hline & ELM3 & N $05^{\circ} 21^{\prime} 22.6^{\prime \prime}$ E $006^{\circ} 30^{\prime} 51.3^{\prime \prime}$ & 1 & 162.14 & 13.3 \\
\hline \multirow[t]{3}{*}{ Trofani } & TFN1 & 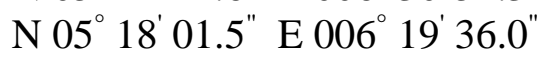 & 1 & 87.61 & 7.2 \\
\hline & TFN2 & N $05^{\circ} 17^{\prime} 58.6^{\prime \prime}$ E $006^{\circ} 19^{\prime} 37.1^{\prime \prime}$ & 1 & 51.50 & 4.2 \\
\hline & TFN3 & N $05^{\circ} 18^{\prime} 17.1^{\prime \prime}$ E $006^{\circ} 19^{\prime} 41.2^{\prime \prime}$ & 1 & 148.51 & 12.2 \\
\hline
\end{tabular}

Table 2: Table showing physiological features of the Soil Mapping Units of Elemebiri and Trofani

\begin{tabular}{|c|c|c|c|c|c|c|}
\hline \multirow[t]{2}{*}{ Horizon } & \multirow{2}{*}{$\begin{array}{l}\text { Depth } \\
\text { (cm) }\end{array}$} & \multicolumn{3}{|c|}{ Percent } & \multirow{2}{*}{$\begin{array}{c}\text { Silt/clay } \\
\text { ratio }\end{array}$} & \multirow{2}{*}{$\begin{array}{c}\text { Textural } \\
\text { Class }\end{array}$} \\
\hline & & Sand & Silt & Clay & & \\
\hline \multicolumn{7}{|c|}{ ELM1 } \\
\hline Ap & $0-8$ & 23 & 67 & 10 & 6.7 & Silt loam \\
\hline Ap2 & $8-21$ & 20 & 62 & 18 & 3.4 & Silt Loam \\
\hline $\mathrm{B} 1$ & $24-34$ & 15 & 54 & 31 & 1.7 & $\begin{array}{l}\text { Silty clay } \\
\text { loam }\end{array}$ \\
\hline B2 & $34-65$ & 14 & 56 & 30 & 1.9 & $\begin{array}{c}\text { Silty clay } \\
\text { loam }\end{array}$ \\
\hline $\mathrm{C} 1$ & $65-90$ & 20 & 70 & 10 & 7 & Silt loam \\
\hline $\mathrm{C} 2$ & $90-118$ & 21 & 69 & 10 & 6.9 & Silt loam \\
\hline $\mathrm{C} 3$ & $118-150$ & 12 & 73 & 15 & 4.9 & Silt loam \\
\hline $\mathrm{C} 4$ & $150-200+$ & 24 & 56 & 20 & 2.8 & Silt loam \\
\hline \multicolumn{7}{|c|}{ ELM2 } \\
\hline Ap & $0-11$ & 18 & 66 & 16 & 4.1 & Silt loam \\
\hline Ap2 & $11-19$ & 22 & 64 & 14 & 4.6 & Silt loam \\
\hline B1 & $19-32$ & 19 & 68 & 13 & 5.2 & Silt loam \\
\hline B2 & $32-42$ & 31 & 57 & 12 & 4.8 & Silt loam \\
\hline B3 & $42-57$ & 28 & 58 & 14 & 4.1 & Silt loam \\
\hline B4 & $57-88$ & 18 & 64 & 18 & 3.6 & Silt loam \\
\hline $\mathrm{C} 1$ & $88-106$ & 12 & 72 & 16 & 4.5 & Silt loam \\
\hline $\mathrm{C} 2$ & $160-190+$ & 24 & 64 & 12 & 5.3 & Silt loam \\
\hline \multicolumn{7}{|c|}{ ELM3 } \\
\hline $\mathrm{A}$ & $0-18$ & 78 & 18 & 4 & 4.5 & Loamy sand \\
\hline Ap & $18-31$ & 72 & 24 & 4 & 6 & Loamy sand \\
\hline Ap2 & $31-44$ & 68 & 28 & 4 & 7 & Sandy loam \\
\hline $\mathrm{C} 1$ & 44.68 & 88 & 10 & 2 & 5 & Loamy sand \\
\hline $\mathrm{C} 2$ & $68-81$ & 78 & 20 & 2 & 10 & Loamy sand \\
\hline $\mathrm{C} 3$ & $81-123$ & 72 & 18 & 10 & 1.8 & Sandy loam \\
\hline $\mathrm{C} 4$ & $123-160$ & 67 & 21 & 12 & 1.8 & Sandy loam \\
\hline $\mathrm{C} 5$ & $160-200+$ & 66 & 19 & 15 & 1.3 & Sandy loam \\
\hline
\end{tabular}


African Journal of Agriculture and Food Science

ISSN: 2689-5331

Volume 4, Issue 3, 2021 (pp. 14-27)

www.abjournals.org

\begin{tabular}{llllccc}
\hline \multicolumn{5}{c}{ TFN1 } & \\
\hline Ap & $0-14$ & 21 & 60 & 19 & 3.2 & Silt loam \\
A & $14-31$ & 21 & 62 & 17 & 3.6 & Silt loam \\
B1 & $31-55$ & 39 & 50 & 11 & 4.5 & Silt loam \\
B2 & $55-140$ & 17 & 66 & 17 & 3.9 & Silt loam \\
B3 & $140-150$ & 11 & 60 & 29 & 2.1 & Silty clay \\
& & & & & & loam \\
C & $150-200+$ & 13 & 66 & 21 & 3.1 & Silt loam \\
\hline & & & TFN2 & & & \\
\hline Ap & $0-11$ & 79 & 17 & 4 & 4.3 & Loamy sand \\
Ap2 & $11-35$ & 15 & 60 & 25 & 2.4 & Silt loam \\
B1 & $35-44$ & 15 & 57 & 28 & 2 & Silty clay \\
& & & & & & loam \\
B2 & $44-70$ & 17 & 60 & 23 & 2.6 & Silt loam \\
C1 & $70-126$ & 31 & 58 & 11 & 5.3 & Silt loam \\
C2 & $126-200+$ & 41 & 49 & 10 & 4.9 & Loam \\
\hline & & & TFN3 & & & \\
\hline A & $0-13$ & 71 & 25 & 4 & 6.3 & Sandy loam \\
Ap1 & $13-23$ & 71 & 27 & 2 & 14 & Sandy loam \\
Ap2 & $23-38$ & 68 & 25 & 7 & 3.6 & Sandy loam \\
C1 & $38-52$ & 67 & 25 & 8 & 3.1 & Sandy loam \\
C2 & $52-69$ & 54 & 36 & 10 & 3.6 & Sandy loam \\
C3 & $69-83$ & 71 & 17 & 12 & 1.4 & Sandy loam \\
C4 & $83-200+$ & 91 & 8 & 1 & 8 & Sand \\
\hline
\end{tabular}




\section{Table 3: Variability of some physical and chemical Properties of Elemebiri Soils}

\begin{tabular}{|c|c|c|c|c|c|c|c|c|c|c|c|c|}
\hline \multirow[t]{2}{*}{ Soil Properties } & \multicolumn{4}{|c|}{ ELM1 } & \multicolumn{5}{|c|}{ ELM2 } & \multicolumn{3}{|c|}{ ELM3 } \\
\hline & Range & $\dot{\mathbf{X}}$ & SD & CV (\%) & Range & $\dot{\mathbf{X}}$ & SD & CV (\%) & Range & $\dot{\mathbf{X}}$ & SD & $\mathrm{CV}(\%)$ \\
\hline $\mathrm{pH}\left(\mathrm{H}_{2} \mathrm{O}\right)$ & $5.46-6.55$ & 5.82 & 0.32 & $5.5 \mathrm{a}$ & $5.44-6.61$ & 6.00 & 0.36 & $5.92 \mathrm{a}$ & $5.31-7.00$ & 5.95 & 0.50 & $8.46 \mathrm{a}$ \\
\hline $\mathrm{pH}\left(\mathrm{CaCl}_{2}\right)$ & $4.94-5.36$ & 5.23 & 0.15 & $2.78 \mathrm{a}$ & $5.17-5.37$ & 5.25 & 0.07 & $1.36 \mathrm{a}$ & $5.19-5.64$ & 5.35 & 0.14 & $2.53 \mathrm{a}$ \\
\hline Org. C (\%) & $0.70-2.25$ & 1.40 & 0.61 & $43.18 \mathrm{c}$ & $0.11-1.03$ & 0.27 & 0.31 & $112.77 \mathrm{c}$ & $0.53-0.84$ & 0.66 & 0.13 & $20.13 b$ \\
\hline Total N (\%) & $0.02-0.25$ & 0.10 & 0.07 & $70.00 \mathrm{c}$ & $0.01-0.09$ & 0.03 & 0.03 & $90.01 \mathrm{c}$ & $0.02-0.07$ & 0.04 & 0.02 & $36.53 c$ \\
\hline $\mathrm{C} / \mathrm{N}$ ratio & $9-21$ & 16.38 & 4.14 & $25.27 \mathrm{~b}$ & $5-21$ & 10.00 & 5.37 & $53.70 \mathrm{c}$ & $8-28$ & 17.13 & 7.34 & $42.84 \mathrm{c}$ \\
\hline Avail $\mathrm{P}\left(\mathrm{mg} \mathrm{kg}^{-1}\right)$ & $5-18$ & 9.13 & 5.36 & $58.71 \mathrm{c}$ & $6-17$ & 10.63 & 4.41 & $41.49 c$ & $5-18$ & 9.88 & 4.49 & $45.43 c$ \\
\hline $\mathrm{Ca}^{2+}$ & $0.71-1.26$ & 0.93 & 0.25 & $26.85 b$ & $0.63-1.95$ & 0.95 & 0.41 & $43.17 \mathrm{c}$ & $0.56-1.28$ & 0.87 & 0.25 & $28.93 b$ \\
\hline $\mathrm{Mg}^{2+}$ & $0.10-1.22$ & 0.52 & 0.34 & $66.60 \mathrm{c}$ & $0.09-0.79$ & 0.39 & 0.28 & $71.98 \mathrm{c}$ & $0.08-0.97$ & 0.47 & 0.33 & $71.39 c$ \\
\hline $\mathrm{K}^{+}$ & $0.18-1.65$ & 0.72 & 0.54 & $75.26 c$ & $0.18-0.70$ & 0.48 & 0.19 & $39.27 \mathrm{c}$ & $0.12-1.81$ & 0.53 & 0.54 & $101.52 \mathrm{c}$ \\
\hline $\mathrm{Na}^{+}$ & $0.06-0.09$ & 0.08 & 0.01 & $13.91 \mathrm{a}$ & $0.03-0.13$ & 0.06 & 0.02 & $36.03 c$ & $0.03-0.08$ & 0.07 & 0.02 & $25.12 b$ \\
\hline TEB $\left(\mathrm{cmol} \mathrm{kg}^{-1}\right)$ & $1.59-4.14$ & 2.24 & 0.56 & $25.06 \mathrm{~b}$ & $1.29-2.57$ & 1.89 & 0.49 & $25.87 b$ & $0.99-3.91$ & 1.93 & 0.95 & $49.10 \mathrm{c}$ \\
\hline Acidity $\left(\mathrm{cmol} \mathrm{kg}^{-1}\right)$ & $1.40-2.50$ & 1.98 & 0.42 & $21.44 b$ & $0.70-2.70$ & 1.70 & 0.68 & $39.76 c$ & $0.50-3.40$ & 1.58 & 0.74 & $46.87 \mathrm{c}$ \\
\hline $\begin{array}{l}\text { Exch. Al }\left(\mathrm{cmol} \mathrm{kg}^{-}\right. \\
\left.{ }_{1}\right)\end{array}$ & $0.70-1.80$ & 1.06 & 0.33 & $30.95 b$ & $16-34$ & 0.90 & 0.27 & $30.29 b$ & $0.30-1.90$ & 0.96 & 0.47 & $49.34 c$ \\
\hline $\operatorname{ECEC~}\left(\mathrm{cmol} \mathrm{kg}^{-1}\right)$ & $3.99-5.62$ & 4.21 & 0.73 & $17.27 \mathrm{~b}$ & $39-68$ & 3.59 & 0.99 & $27.44 b$ & $1.49-6.11$ & 3.58 & 1.64 & $45.74 c$ \\
\hline $\mathrm{BS}(\%)$ & $41-62$ & 53.63 & 8.52 & $15.89 b$ & $39-68$ & 59.00 & 9.67 & $16.39 b$ & $40-66$ & 61.88 & 9.28 & $15.00 \mathrm{a}$ \\
\hline $\mathrm{Al}(\%)$ & $14-46$ & 26.38 & 10.18 & 38.590 & $16-34$ & 25.50 & 5.58 & $21.88 b$ & $16-34$ & 26.88 & 6.58 & $24.48 b$ \\
\hline Sand $(\%)$ & $14-24$ & 18.63 & 4.41 & $23.66 \mathrm{~b}$ & $12-31$ & 21.50 & 6.09 & $28.35 b$ & $66-88$ & 73.63 & 7.41 & $10.06 a$ \\
\hline Silt (\%) & $54-73$ & 63.38 & 7.37 & $11.62 \mathrm{a}$ & $57-72$ & 64.13 & 4.91 & $7.66 \mathrm{a}$ & $10-28$ & 19.75 & 5.20 & $26.34 b$ \\
\hline Clay (\%) & $10-31$ & 18.00 & 8.60 & $47.97 \mathrm{c}$ & $12-18$ & 14.38 & 2.13 & $14.84 \mathrm{a}$ & $2-15$ & 6.63 & 4.98 & $75.23 c$ \\
\hline Silt/clay ratio & $1.7-7$ & 4.41 & 2.26 & $51.16 \mathrm{c}$ & $3.6-5.2$ & 4.53 & 0.58 & 12.82 & $1.3-10$ & 4.67 & 3.01 & $64.45 c$ \\
\hline
\end{tabular}

$\dot{\mathrm{X}}=$ mean, $\mathrm{SD}=$ standard deviation, $\mathrm{CV}=$ coefficient of variation, where 'a' is $<15 \%=$ least variable, ' $\mathrm{b}$ ' is $15-35 \%=$ moderately variable, 'c' is $>35 \%=$ highly variable. 
Table 4: Variability of some physical and chemical Properties of Trofani Soils

\begin{tabular}{|c|c|c|c|c|c|c|c|c|c|c|c|c|}
\hline \multirow[t]{2}{*}{ Soil Properties } & \multicolumn{4}{|c|}{ TFN1 } & \multicolumn{4}{|c|}{ TFN2 } & \multicolumn{4}{|c|}{ TFN3 } \\
\hline & Range & $\dot{\mathbf{X}}$ & SD & $\mathrm{CV}(\%)$ & Range & $\dot{\mathbf{X}}$ & SD & $\mathrm{CV}(\%)$ & Range & $\dot{\mathbf{X}}$ & SD & $\mathrm{CV}(\%)$ \\
\hline $\mathrm{pH}\left(\mathrm{H}_{2} \mathrm{O}\right)$ & $5.30-5.95$ & 5.72 & 0.20 & $3.55 \mathrm{a}$ & $5.98-6.80$ & 6.27 & 0.29 & $4.64 \mathrm{a}$ & $5.55-6.11$ & 5.90 & 0210 & $3.64 \mathrm{a}$ \\
\hline $\mathrm{pH}\left(\mathrm{CaCl}_{2}\right)$ & $5.09-5.39$ & 5.21 & 0.11 & $2.02 \mathrm{a}$ & $4.90-5.35$ & 5.13 & 0.16 & $3.11 \mathrm{a}$ & $4.98-5.33$ & 5.19 & 0.12 & $2.39 \mathrm{a}$ \\
\hline Org. C (\%) & $0.21-1.60$ & 0.78 & 0.57 & $72.45 c$ & $0.19-1.28$ & 0.49 & 0.41 & $84.63 c$ & $0.08-1.20$ & 0.63 & 0.33 & $52.71 \mathrm{c}$ \\
\hline Total N (\%) & $0.02-0.13$ & 0.06 & 0.04 & $67.55 c$ & $0.02-0.06$ & 0.04 & 0.02 & $46.94 c$ & $0.01-0.10$ & 0.06 & 0.03 & $47.09 \mathrm{c}$ \\
\hline $\mathrm{C} / \mathrm{N}$ ratio & $8-26$ & 12.75 & 6.16 & $48.31 \mathrm{c}$ & $10-21$ & 12.67 & 4.18 & $32.99 \mathrm{~b}$ & $8-12$ & 11.17 & 0.75 & $6.74 a$ \\
\hline Avail $\mathrm{P}\left(\mathrm{mg} \mathrm{kg}^{-1}\right)$ & $8-16$ & 9.50 & 4.00 & $42.11 \mathrm{c}$ & $2-17$ & 10.67 & 6.09 & $57.08 \mathrm{c}$ & $3-15$ & 7.67 & 4.55 & $59.32 c$ \\
\hline $\mathrm{Ca}^{2+}$ & $0.56-0.78$ & 0.74 & 0.07 & $10.01 \mathrm{a}$ & $0.75-1.83$ & 1.22 & 0.50 & $41.33 c$ & $0.74-1.24$ & 0.88 & 0.19 & $22.08 \mathrm{~b}$ \\
\hline $\mathrm{Mg}^{2+}$ & $0.12-0.98$ & 0.35 & 0.28 & $80.29 c$ & $0.12-0.89$ & 0.48 & 0.28 & $71.97 \mathrm{c}$ & $0.06-1.01$ & 0.56 & 0.73 & $66.79 c$ \\
\hline $\mathrm{K}^{+}$ & $0.15-0.65$ & 0.41 & 0.24 & $60.25 c$ & $0.14-1.88$ & 0.54 & 0.67 & $123.39 \mathrm{c}$ & $0.19-0.94$ & 0.54 & 0.24 & $45.46 c$ \\
\hline $\mathrm{Na}^{+}$ & $0.03-0.07$ & 0.06 & 0.01 & $23.81 \mathrm{~b}$ & $0.05-0.08$ & 0.07 & 0.01 & $15.64 b$ & $0.07-0.09$ & 0.08 & 0.01 & $11.16 \mathrm{a}$ \\
\hline TEB $\left(\mathrm{cmol} \mathrm{kg}^{-1}\right)$ & $0.97-2.07$ & 1.56 & 0.44 & $28.22 b$ & $1.09-3.24$ & 2.30 & 0.79 & $34.30 \mathrm{~b}$ & $1.10-2.72$ & 2.05 & 0.95 & $49.10 \mathrm{c}$ \\
\hline Acidity $\left(\mathrm{cmol} \mathrm{kg}^{-1}\right)$ & $1.70-5.40$ & 2.43 & 1.21 & $50.06 c$ & $0.80-3.30$ & 1.88 & 0.95 & $50.29 c$ & $1.40-4.60$ & 2.18 & 1.20 & $55.02 \mathrm{c}$ \\
\hline Exch. $\mathrm{Al}\left(\mathrm{cmol} \mathrm{kg}^{-1}\right)$ & $0.80-2.40$ & 1.30 & 0.52 & $39.62 c$ & $0.50-1.90$ & 0.97 & 0.51 & $53.05 \mathrm{c}$ & $0.70-2.20$ & 1.17 & 0.53 & $45.59 \mathrm{c}$ \\
\hline $\operatorname{ECEC~}\left(\mathrm{cmol} \mathrm{kg}^{-1}\right)$ & $2.89-6.37$ & 3.98 & 1.112 & $28.19 b$ & $2.79-6.29$ & 4.19 & 1.37 & $32.62 b$ & $3.07-5.70$ & 4.23 & 0.93 & $22.02 \mathrm{~b}$ \\
\hline $\mathrm{BS}(\%)$ & $15-53$ & 41.13 & 12.44 & $30.25 b$ & $38-77$ & 55.83 & 14.80 & $26.51 b$ & $19-60$ & 50.17 & 15.41 & $30.72 b$ \\
\hline $\mathrm{Al}(\%)$ & $18-39$ & 32.88 & 7.51 & $22.84 b$ & $14-35$ & 23.33 & 8.41 & $36.05 c$ & $20-39$ & 27.00 & 6.29 & $23.30 \mathrm{~b}$ \\
\hline Sand $(\%)$ & $11-39$ & 18.63 & 4.41 & $23.66 b$ & $15-79$ & 21.50 & 6.09 & $28.35 b$ & $54-91$ & 73.63 & 7.41 & $10.06 \mathrm{a}$ \\
\hline Silt (\%) & $50-66$ & 63.38 & 7.37 & $11.62 \mathrm{a}$ & $17-60$ & 64.13 & 4.91 & $7.66 \mathrm{a}$ & $8-36$ & 19.75 & 5.20 & $26.34 b$ \\
\hline Clay $(\%)$ & $11-29$ & 18.00 & 8.60 & $47.97 \mathrm{c}$ & $4-28$ & 14.38 & 2.13 & $14.84 \mathrm{a}$ & $1-12$ & 6.63 & 4.98 & $75.23 c$ \\
\hline Silt/clay ratio & $0.70-4.5$ & 3.40 & 0.70 & $20.50 \mathrm{~b}$ & $2.0-5.3$ & 3.58 & 1.42 & $39.60 \mathrm{c}$ & $1.4-14$ & 5.33 & 4.53 & $84.99 \mathrm{c}$ \\
\hline
\end{tabular}

$\dot{\mathrm{X}}=$ mean, $\mathrm{SD}=$ standard deviation, $\mathrm{CV}=$ coefficient of variation, where ' $\mathrm{a}$ ' is $<15 \%=$ least variable, ' $\mathrm{b}$ ' is $15-35 \%=$ moderately variable, 'c' is $>35 \%=$ highly variable. 